\title{
Aplikasi Informasi Stok Barang Pada Toko Online Berbasis Web
}

\author{
${ }^{1}$ Aji Sudarsono \\ ${ }^{1}$ Dosen Tetap Program Studi Teknik Informatika Fakultas Ilmu Komputer Universitas Dehasen Bengkulu \\ Jl. Meranti Raya No. 32 Kota Bengkulu 38228 Telp. (0736) 22027, 26957 Fax. (0736) 341139 \\ Email : ${ }^{1}$ ajisudarsono27@gmail.com
}

\begin{abstract}
Abstack - This research will generate an application that can be used in any goods store, this application responds to problems that are often found in the case of other applications, the application can display stock information generated by the goods based on stock data that is inputed on the purchase form of goods. Cashier can carry out the sale of goods by entering the data of goods that want to be purchased by consumers, if the stock of goods requested on the sales transaction is smaller than the stock of existing goods then the sales process in progress, but if the demand for stock goods are larger than stock it will appear a notification that the stock of the requested item is exhausted.
\end{abstract}

Keywords: applications, information items stock, WEB

Abstrak - Penelitian ini akan menghasilkan sebuah aplikasi yang dapat digunakan dalam toko barang manapun, aplikasi ini menjawab masalah yang sering ditemukan dalam kasus aplikasi lain, aplikasi ini dapat menampilkan informasi stok barang yang dihasilkan berdasarkan data stok barang yang diinputkan pada form pembelian barang. Kasir dapat melakukan transaksi penjualan barang dengan memasukkan data barang yang ingin dibeli oleh konsumen, jika stok barang yang diminta pada transaksi penjualan lebih kecil dari stok barang yang ada maka proses penjualan dalam berjalan, namun apabila permintaan stok barang lebih besar dari stok maka akan muncul notifikasi bahwa stok barang yang diminta habis.

Kata Kunci : Aplikasi, Informasi Stok barang, Web

\section{Pendahuluan}

Kemajuan teknologi yang begitu cepat mampu menghasilkan beberapa aplikasi yang mampu memudahkan para pengguna dalam melakukan proses kegiatan sehari-hari, sebagai contoh pada industry perdagangan. Baik dalam proses pembelian dan penjulan suatu barang. Diantara banyak aplikasi tersebut banyak kita temui beberapa aplikasi yang belum sempurna dan butuh pengembangan lebih lanjut. Untuk itu penulis tertarik memberikasan suatu bentuk aplikasi yang mampu menampilkan informasi persedian stok suatu barang.

Persediaan atau stok barang selalu diperlukan dalam aktivitas penjualan. Keberadaan persediaaan barang disatu pihak merupakan pemborosan sehingga dapat dikatakan suatu beban yang harus dihilangkan, tetapi dilain pihak sangan diperlukan untuk menjamin kelancaran pemenuhan permintaan sebab bila tidak ada persediaan maka kebutuhan tidak terpenuhi. Kemajuan atau keberhasilan suatu perusahaan salah satunya dipengaruhi oleh pengendalian persediaan. Pengendalian persediaan diharapkan dapat mengingkatkan keuntungan sehingga meminimumkan biaya yang ditimbulkan ${ }^{1}$.
Masalah yang sering terjadi dengan sistem persediaan berdasarkan pengalaman sales manager dan kepala administrasi adalah jumlah barang yang disimpan terlalu banyak. Barang yang terlalu banyak disimpan, seringkali tidak laku atau lama terjual. Dengan kata lain, terjadi penumpukkan persediaan yang disebut overstock yang menyebabkan kerugian bagi perusahaan karena terjadi pemborosan tempat yang seharusnya dapat digunakan untuk menyimpan barang lain. Masalah lain yang sering dialami adalah masalah kekurangan barang di gudang. Persediaan untuk beberapa jenis barang yang terlalu sedikit mengakibatkan permintaan dari konsumen tidak bisa dipenuhi tepat waktu.Keadaan dimana barang yang disimpan terlalu sedikit mengakibatkan biaya backorder atau lost sales yang mengkibatkan kerugian $^{2}$.

Untuk melihat dan mendapatkan jumlah persediaan barang yang tepat dan terkontrol, pihak perusahaan bisa mengamati dari transaksi pembelian dan penjualan. Sehingga bisa mendapatkan informasi yang digunakan untuk keperluan pengendalian persediaan barang seperti menentukan jumlah barang yang harus disiapkan di 
gudang, mengatur jumlah minimal stok dan menentukan stok aman. Selain itu dengan informasi ini perusahaan dapat menentukan kapan mereka harus memperbaharui stok ${ }^{1}$.

\section{Landasan Teori}

A. Aplikasi

Aplikasi berasal dari kata application yang artinya penerapan, lamaran, penggunaan. Secara istilah aplikasi adalah: program siap pakai yang direka untuk melaksanakan suatu fungsi bagi pengguna atau aplikasi yang lain dan dapat digunakan oleh sasaran yang dituju ${ }^{3}$.

B. Persediaan

Pengertian mengenai persediaan dalam hal ini adalah sebagai suatu aktiva yang meliputi barangbarang milik perusahaan dengan maksud untuk dijual dalam suatu periode usaha tertentu, atau persediaan barang-barang yang masih dalam pengerjaan / proses produksi, ataupun persediaan bahan baku yang menunggu penggunaannya dalam suatu proses produksi. Jadi persediaan merupakan sejumlah bahan-bahan, bagian-bagian yang disediakan dan bahan-bahan dalam proses yang terdapat dalam perusahaan untuk proses produksi, serta barang-barang jadi / produk yang disediakan untuk memenuhi permintaan dari konsumen atau langganan setiap waktu. Nilai ekonomis persediaan timbul karena sumber daya tersebut diperoleh dengan suatu pengorbanan dengan harapan untuk memenuhi kebutuhan di masa yang akan datang. Definisi lain menyatakan bahwa pada dasarnya persediaan adalah suatu sumber daya menganggur (idle resources) yang menunggu proses lebih lanjut. Yang dimaksud proses lebih lanjut di sini dapat berupa kegiatan produksi seperti yang dijumpai pada sistem industri, kegiatan pemasaran seperti dijumpai pada sistem distribusi ataupun kegiatan konsumsi ${ }^{4}$.

Pengadaan persediaan harus diperhatikan karena berkaitan langsung dengan biaya yang harus ditanggung perusahaan sebagai akibat adanya persediaan.Oleh sebab itu, persediaan yang ada harus seimbang dengan kebutuhan,karena persediaan yang terlalu banyak akan mengakibatkan perusahaan menanggung resiko kerusakan dan biaya penyimpanan yang tinggi disamping biaya investasi yang besar. Banyak cara dilakukan perusahaan untuk menarik minat pelanggan. Salah satunya adalah dengan memberikan sistem diskon pada pembeli yang juga dapat menurunkan biaya-biaya persediaan pada perusahaa banyak dikembangkan penelitian model persediaan yang mempertimbangkan diskon dan waktu kadaluarsa yang bertujuan untuk meminimalkan biaya total persediaan yang ada ${ }^{5}$.

C. Pegertian Web

Pada awalnya aplikasi web dibangun dengan hanya menggunakan bahasa yang disebut HTML (HyperText Markup Langauge). Pada perkembangan berikutnya, sejumlah skrip dan objek dikembangkan untuk memperluas kemampuan HTML seperti PHP dan ASP pada skrip dan Apllet pada objek. Aplikasi Web dapat dibagi menjadi dua jenis yaitu aplikasi web statis dan dinamis ${ }^{6}$.

Web statis dibentuk dengan menggunakan HTML. Kekurangan aplikasi seperti ini terletak pada keharusan untuk memelihara program secara terus menerus untuk mengikuti setiap perkembangan yang terjadi. Kelemahan ini diatasi oleh model aplikasi web dinamis. Pada aplikasi web dinamis, perubahan informasi dalam halaman web dilakukan tanpa perubahan program tetapi melalui perubahan data. Sebagai implementasi, aplikasi web dapat dikoneksikan ke basis data sehingga perubahan informasi dapat dilakukan oleh operator dan tidak menjadi tanggung jawab dari webmaster ${ }^{7}$.

Arsitektur aplikasi web meliputi klien, web server, middleware dan basis data. Klien berinteraksi dengan web server. Secara internal, web server berkomunikasi dengan middleware dan middleware yang berkomunikasi dengan basis data. Contoh middleware adalah PHP dan ASP. Pada mekanisme aplikasi web dinamis, terjadi tambahan proses yaitu server menerjemahkan kode PHP menjadi kode HTML. Kode PHP yang diterjemahkan oleh mesin PHP yang akan diterima oleh klien ${ }^{7}$.

\section{Metode Penelitian}

Dalam pembangunan aplikasi ini menggunakan perancangan waterfall. Menurut Sommerville (2011, hlm.29) model waterfall adalah model waterfall ini membutuhkan kegiatan proses spesifikasi, pengembangan, validasi, evolusi dan mewakili sistem sebagai proses terpisah dan mempunyai fase seperti persyaratan spesifikasi, desain perangkat lunak, implementasi, pengujian dan sebagainya. Sommerville (2011, hlm.30) mengungkapkan bahwa model waterfall tersusun dalam beberapa tahapan penelitian sebagai berikut :

1) Requirement Definition (persyaratan definisi, analisis)

2) System and Software Design (desain sistem dan perangkat lunak)

3) Implementation and Unit Testing (pelaksanaan dan unit pengujian)

4) Integration and System Testing (integrasi dan sistem pengujian)

5) Operation And Maintenance (operasi dan pemeliharaan)

Model pengembangan waterfall yang diungkapkan

27 | http://www.jurnal.umb.ac.id/index.php/JTIS 
Ian Sommerville bisa digambarkan sebagai berikut

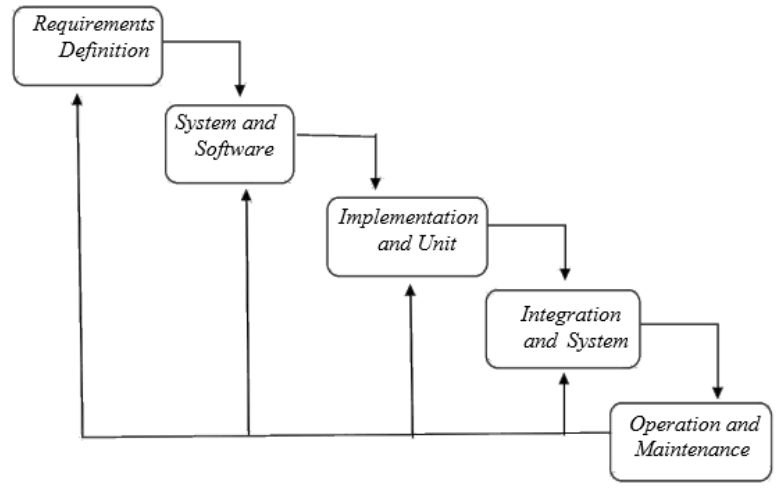

Gbr 1 Waterfall Model

Berikut Merupakan rancangan Diagram Aplikasi

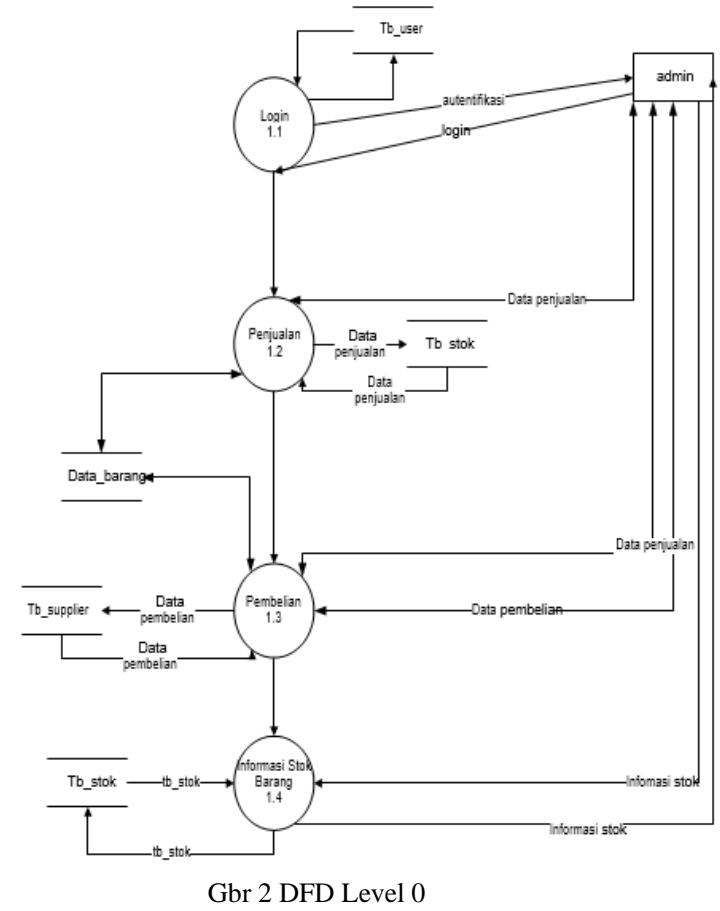

Rencangan ERD

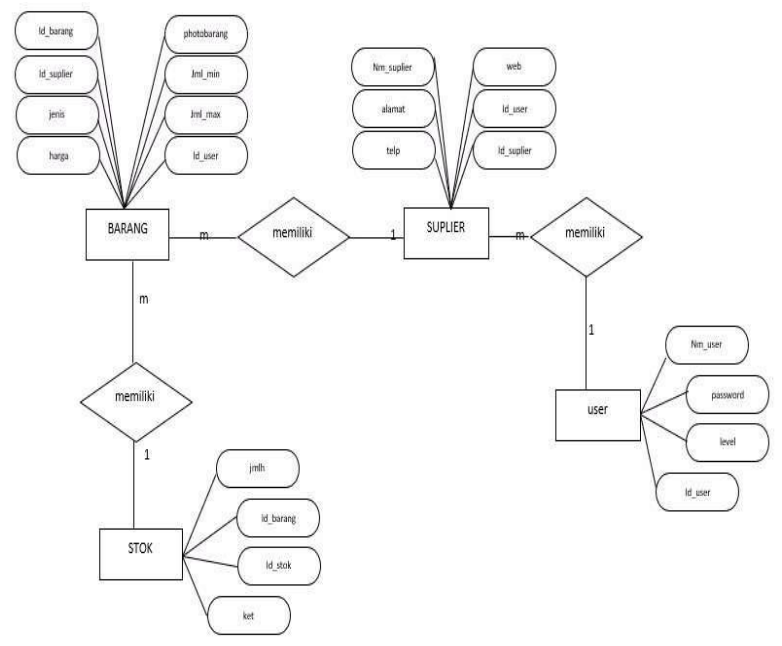

Gbr 3. ERD
IV. Hasil dan Pembahasan

A. Hasil dan Pembahasan

Hasil rancangan aplikasi kemudian menghasilkan aplikasi stok barang, adapun tampilan aplikasi informasi stok barang adalah sebagai berikut :

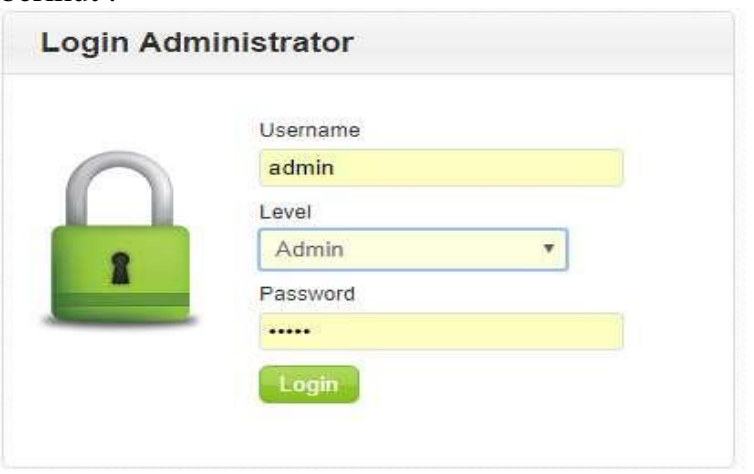

Gbr 4. Login Aplikasi
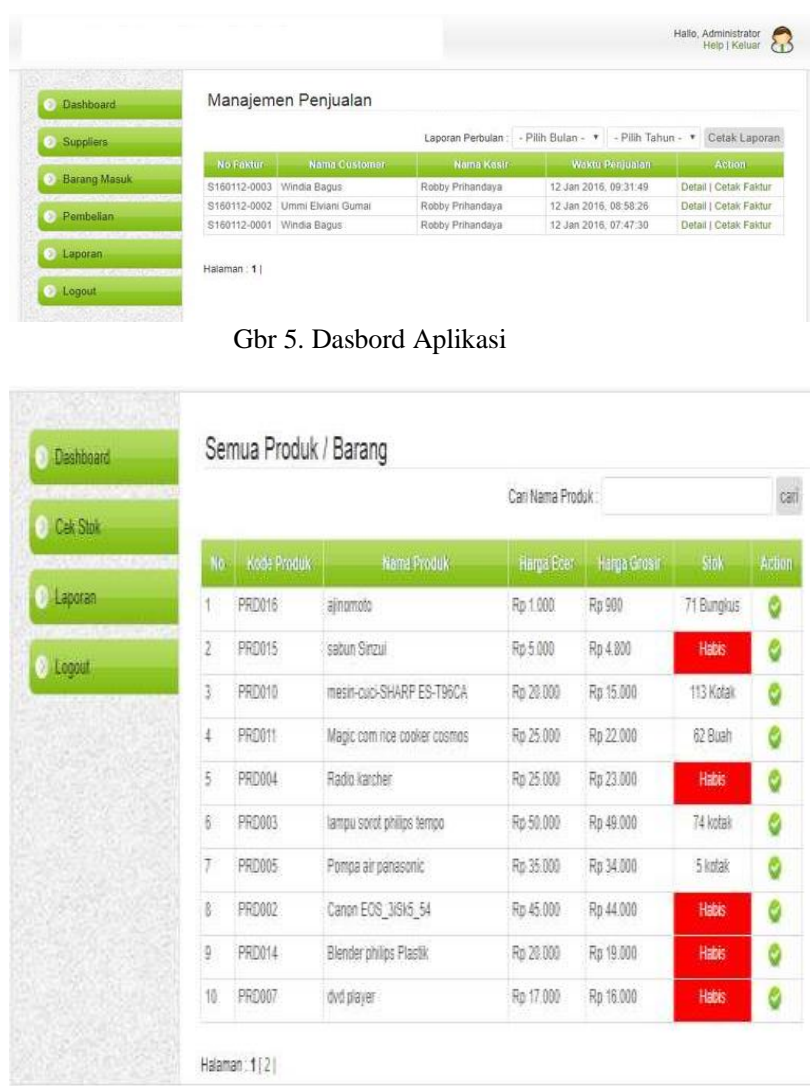

Gbr 6 Tampilan Informasi Stok Barang

B. Pengujian Aplikasi

Pengujian Black Box dilakukan untuk menguji apakah sistem yang dikembangkan sesuai dengan apa yang tertuang didalam spesifikasi fungsional sistem. Pengujian Black Box juga digunakan untuk menguji fungsi-fungsi khusus dari sistem yang dirancang. Kebenaran sistem yang diuji hanya dilihat berdasarkan keluaran yang 
dihasilkan dari data atau kondisi masukan yang diberikan untuk fungsi yang ada tanpa melihat bagaimana proses untuk mendapatkan keluaran tersebut.Pengujian Black Box dilakukan dengan menguji setiap aktivitas yang terdapat di halaman aplikasi Informasi stok barang, setelah aplikasi dijalankan. Pengujian dan hasil uji black box dapat dilihat pada Tabel dibawah ini :

Tabel 1 Hasil Pengujian

\begin{tabular}{|c|c|c|}
\hline Aktivitas Pengujian & $\begin{array}{l}\text { Realisasi Yang di } \\
\text { Harapkan }\end{array}$ & Hasil \\
\hline $\begin{array}{l}\text { Klik menu login pilih } \\
\text { level admin }\end{array}$ & $\begin{array}{l}\text { Masuk ke aplikasi sesuai } \\
\text { hak akses yang di miliki } \\
\text { oleh pengguna. Masuk ke } \\
\text { dashboard aplikasi }\end{array}$ & Sukses \\
\hline Dashboard admin & $\begin{array}{l}\text { Menampilkan } \\
\text { beranda. }\end{array}$ & Sukses \\
\hline Klik menu suplier & $\begin{array}{l}\text { Menampilkan tabel } \\
\text { informasi supplier produk }\end{array}$ & Sukses \\
\hline $\begin{array}{l}\text { Tambah data } \\
\text { supplier }\end{array}$ & $\begin{array}{l}\text { Menampilkan halaman } \\
\text { tambah supplier }\end{array}$ & Sukses \\
\hline $\begin{array}{l}\text { Klik tombol simpan } \\
\text { pada halaman } \\
\text { supplier }\end{array}$ & $\begin{array}{l}\text { Menyimpan data } \\
\text { supplier }\end{array}$ & Sukses \\
\hline Klik menu Barang & $\begin{array}{l}\text { Menampilkan tabel } \\
\text { informasibarang }\end{array}$ & Sukses \\
\hline $\begin{array}{l}\text { Tambah data } \\
\text { barang }\end{array}$ & $\begin{array}{l}\text { Menampilkan halaman tambah } \\
\text { barang }\end{array}$ & Sukses \\
\hline $\begin{array}{l}\text { Klik } \\
\text { menu } \\
\text { nembelia } \\
\end{array}$ & $\begin{array}{l}\text { Menampilkan informasi } \\
\text { pembelian }\end{array}$ & Sukses \\
\hline $\begin{array}{l}\text { Klik menu } \\
\text { laporan produk }\end{array}$ & $\begin{array}{l}\text { Menampilkan halaman cetak } \\
\text { lapuran produk }\end{array}$ & Sukses \\
\hline $\begin{array}{l}\text { Melakukan login } \\
\text { sebagai kasir }\end{array}$ & $\begin{array}{l}\text { Menampilkan menu- menu } \\
\text { kasir }\end{array}$ & Sukses \\
\hline $\begin{array}{l}\text { Klik menu cek } \\
\text { stok }\end{array}$ & $\begin{array}{l}\text { Menampilkan halaman } \\
\text { cek stok }\end{array}$ & Sukses \\
\hline
\end{tabular}

\section{Penutup}

A. Kesimpulan

Dari penelitian ini ditarik beberapa kesimpulan diantaranya :

1. Aplikasi yang dihasilkan dapat melakukan perhitungan jumlah stok dan menampilkan informasi data stok barang berdasarkan jumlah pembelian barang baru

2. Jumlah informasi stok barang akan berkurang apabila jumlah data penjualan dilakukan, stok barang akan berkurang otomatis jika jumlah barang yang dibeli memenuhi jumlah stok barang yang tersedia

3. Jika jumlah barang yang diminta pada proses penjualan melebihi jumlah stok barang yang ada maka akan muncul notifikasi stok barang habis.

B. Saran
1. Aplikasi ini masih dapat dikembangkan lagi menggunakan algoritma dalam proses transaksinya, baik penjualan maupun transaksi pemebelian barang.

2. Aplikasi ini bisa digunakan pada toko barang apapun, dan dapat dijalankan pada web browser manapun.

\section{Referensi}

[1] Nurul Novianti Bustaman,(2013). Pengendalian Persediaan Barang dengan model probabilistk. Universitas Pendidikan Indonesia, hal 3.

[2] Rahmawati.(2017). Sistem Informasi Inventory. Teknik Informatika, hal 20.

[3] Gunawan, G., \& Kirman, K. (2019). Implementasi Algoritma Turbo Boyer Moore untuk Pencarian Data pada Transaksi Keuangan Duta Phonecell Sawah Lebar. JURNAL MEDIA INFOTAMA, 15(1).

[4] Haruddin dan Muhammad Fitra (2016). Pengendalian Persediaan Bahan Baku Reactor Coating Solution1(Rcs-1) Dalam Mengefisienkan Biaya Persediaan. Politeknik ATI Makassar

[5] Agus Ristono, 2009, Manajemen Persediaan, Graha Ilmu, Yogyakarta. Andrea

[6] A.S, R., dan Shalahudin, M. (2014). Rekaya Perangkat Lunak Terstruktur dan Berorientasi Objek. Bandung: Informatika Bandung.

[7] Abdul Kadir., 2009. MasteringAjax dan Php. Penerbit Andi, Yogyakarta.

[8] Sommerville, Ian. 2011. Software Engineering (Rekayasa Perangkat Lunak). Jakarta: Erlangga. 